\title{
Peran Mediasi Workplace Spirituality pada Pengaruh Spiritual Leadership terhadap Organization Citizenship Behavior
}

Submitted Date :

6 June 2021

Accepted Date :

27 October 2021

\author{
Jufrizen* \\ Universitas Muhammadiyah Sumatera Utara \\ Jalan Kapten Muchtar Basri No. 3 Medan, Indonesia \\ jufrizen@umsu.ac.id \\ Abdul Hakim Nasution \\ Universitas Muhammadiyah Sumatera Utara \\ Jalan Kapten Muchtar Basri No. 3 Medan, Indonesia \\ abduhakimnst@gmail.com
}

\section{Suggested Citation:}

Jufrizen, J., Sari, M., Nasution, M. I., Radiman, R., \& Wahyuni, S. F. (2019). The Strategy of Spiritual Leadership : The Role of Spiritual Survival, Workplace Spirituality and Organizational Commitment at Private Universities. International Journal of Research in Business and Social Science, 8(1), 64-72.

Abstract:

The purpose of this study was to determine and analyze the influence of the Mediation role of Workplace Spirituality on the Effect of Spiritual Leadership on Organizational Citizenship Behavior on Administrative Employees at the State Islamic University of North Sumatra, directly or indirectly. The approach used in this study is a causal approach. The population in this study were all administrative staff at the State Islamic University of North Sumatra. The sample in this study using the slovin formula totaling 66 administrative employees at the State Islamic University of North Sumatra. Data collection techniques in this study used interview techniques and questionnaires. The data analysis technique in this study uses a quantitative approach using statistical analysis by using the Auter Model Analysis test, Inner Model Analysis, and Hypothesis Testing. Data processing in this study using the PLS (Partial Least Square. The results of this study prove that Spiritual Leadership directly has a significant effect on Organizational Citizenship Behavior. Spiritual Leadership directly has a significant effect on Workplace Spirituality. Directly Workplace Spirituality has a significant effect Organizational Citizenship Behavior and Spiritual Leadership has a significant effect on Organizational Citizenship Behavior mediated by Workplace Spirituality on administrative staff at the State Islamic University of North Sumatra.

Keywords: Workplace Spirituality, Spiritual Leadership, Organization Citizenship Behavior

Abstrak:

Tujuan penelitian ini adalah untuk mengetahui dan menganalisis pengaruh Peran Mediasi Workplace Spirituality pada Pengaruh Spiritual Leadership Terhadap Organization Citizenship Behavior Pada Pegawai Adminitrasi Di Universitas Islam Negeri Sumatera Utara secara langsung maupun secara tidak langsung. Pendekatan yang digunakan dalam penelitian ini adalah pendekatan kausal. Populasi dalam penelitian ini adalah seluruh Pegawai Adminitrasi Di Universitas Islam Negeri Sumatera Utara. Sampel dalam penelitian ini menggunakan rumus slovin berjumlah 66 orang Pegawai Adminitrasi Di Universitas Islam Negeri Sumatera Utara. Teknik pengumpulan data dalam penelitian ini menggunakan teknik wawancara dan angket. Teknik analisis data dalam penelitian ini menggunakan pendekatan kuantitatif menggunakan analisis statistik dengan menggunkana uji Analisis Auter Model, Analisis Inner Model, dan Uji Hipotesis. Pengolahan data dalam penelitian ini menggunakan PLS (Partial Least Square). Hasil penelitian ini membuktikan bahwa secara langsung Spiritual Leadership berpengaruh signifikan terhadap Organization Citizenship Behavior. Secara langsung Spiritual Leadership berpengaruh signifikan terhadap Workplace Spirituality. Secara langsung Workplace Spirituality berpengaruh signifikan terhadap Organization Citizenship Behavior dan Spiritual Leadership berpengaruh signifikan terhadap Organization Citizenship Behavior yang dimediasi oleh Workplace Spirituality pada pegawai adminitrasi Universitas Islam Negeri Sumatera Utara.

Kata Kunci: Workplace Spirituality, Spiritual Leadership, Organization Citizenship Behavior

JEL Classification: 015, P17, J53

${ }^{*}$ Corresponding Author 


\section{Latar Belakang}

Organisasi merupakan suatu persekutuan antara dua orang atau lebih yang bekerja sama untuk mencapai tujuan yang telah ditetapkan, yang merupakan hubungan antara bawahan dengan atasan. Dari organisasi timbul pengelompokan manusia atas pimpinan pempinan dan bawahan yang harus bekerja sama dan didasarkan pada pembagian tugas, wewenang dan tanggung jawab (Arianty, 2015). Kunci keberhasilan organisasi adalah bagaimana anggota organisasi dapat memberikan kontribusi positif pada pencapaian tujuan organisasi. Organisasi membutuhkan anggota yang mau melakukan lebih dari sekedar tugas biasa dan memberikan kinerja yang melebihi harapan. Dalam dunia kerja yang dinamis seperti sekarang ini, disaat tugas semakin sering dikerjakan dalam tim, organisasi menjadi sangat membutuhkan anggota yang mampu menampilkan peran ekstra (Helmy, 2016).

Perilaku peran ekstra atau disebut juga sebagai Organizational Citizenship Behavior (OCB). OCB adalah perilaku perilaku diskresioner yang secara eksplisit atau secara tidak langsung diakui oleh sistem formal, dan secara agregat berfungsi dengan efektif dan efisien dalam sebuah organisasi. OCB juga menggambarkan bentuk perilaku prososial yang terdiri dari perilaku sosial positif, konstruktif dan bermakna membantu (Organ, Podsakoff, \& MacKenzie, 2006). Di dalam organisasi yang memiliki kompleksitas tugas dan lingkungan, sangat dibutuhkan peran ekstra (extra role)" pegawai dalam melaksanakan tugasnya, tidak hanya peran "in-role". Seseorang yang memiliki tingkat OCB yang tinggi akan memiliki loyalitas dan pengabdian pada organisasinya (Nooralizad, dkk 2011) serta berpengaruh terhadap efektivitas individu maupun organisasi (Podsakoff, dkk 2006).

Organizational Citizenship Behavior (OCB) berpusat kepada perilaku tiap individu yang melaksanakan tugasnya yang melebihi dari deskripsi kerjanya. OCB adalah perilaku karyawan yang melebihi peran yang diwajibkan, yang tidak secara langsung atau eksplisit diakui oleh sistem reward formal. Menurut Djati, (2009) memberikan pengertian OCB sebagai bentuk perilaku yang merupakan pilihan dan inisiatif individual untuk meningkatkan efiseinsi kinerja organisasi dengan membantu tujuan dari produktifitas individu pegawai.

Menurut Adhiyana, (2006) OCB merupakan kontribusi individu yang melebihi tuntutan peran di tempat kerja dan di-reward oleh perolehan kinerja tugas. OCB ini melibatkan beberapa perilaku meliputi perilaku menolong orang lain, menjadi volunteer untuk tugas-tugas ekstra, patuh terhadap aturan-aturan dan prosedurprosedur di tempat kerja. Selanjutnya menurut (Aldag \& Reschake, 1997) perilaku-perilaku ini menggambarkan "nilai tambah karyawan" yang merupakan salah satu bentuk perilaku pro sosial, yaitu perilaku sosial yang positif, konstruktif dan bermakna membantu.

Oganizational Citizenship Behavior (OCB) merupakan kontribusi individu yang dalam melebihi tuntutan peran di tempat kerja dan di-reward oleh perolehan kinerja tugas. Faktor-faktor yang mempengaruhi timbulnya OCB cukup kompleks dan saling terkait satu sama lain. Menurut Novaliadi, (2007) faktor-faktor yang mempengaruhi OCB adalah Budaya dan iklim organisasi, Kepribadian dan suasan hati (mood), Persepsi terhadap dukungan organisasional, Persepsi terhadap interaksi atasan-bawahan, Masa kerja dan Jenis kelamin. Sedangkan menurut Djat (2009) mengemukakan tiga indikator OCB yaitu:1) Ketaatan (Obedience) yang menggambarkan kemauan karyawan untuk menerima dan mematuhi peraturan dan prosedur organisasi. 2) Loyalitas (Loyality) yang menggambarkan kemauan karyawan untuk menempatkan kepentingan pribadi mereka untuk keuntungan dan kelangsungan organisasi, dan 3) Partisipasi (Participation) yang menggambarkan kemauan karyawan untuk secara aktif mengembangkan seluruh aspek kehidupan organisasi.

Pemimpin memainkan peran penting dalam membentuk OCB. Hasil penelitian menunjukkan bahwa kepemimpinan memiliki pengaruh terhadap OCB (Setiani \& Hidayat, 2020, \& Nurcahyo, 2012). Untuk menumbuhkan jiwa OCB dibutuhkan pemimpin yang lebih baik dan lebih etis. Spiritual leadership merupakan sebagai kumpulan dari nilai-nilai, tingkah laku, dan kebiasaan yang merupakan bahan penting untuk memotivasi seseorang dan orang lain dari dalam dirinya sendiri (Fry, Vitucci, \& Cedillo, 2005). Spiritual leadership merupakan kepemimpinan yang membentuk values, attitude, behavior yang dibutuhkan untuk memotivasi diri sendiri dan orang lain secara intrinsic motivation sehingga menggapai rasa spiritual survival (Thayib, dkk 2013). Selanjutnya Fry, dkk (2005) menjelaskan salah satu hal yang berkaitan dengan efektifitas sebuah kepemimpinan ditempat kerja, tidak terlepas dari sebuah nilai nilai spiritual. Oleh karena itu merupakan sebuah hal yang penting untuk menanamkan nilai moral spiritual pada seluruh pegawai. Sedangkan menurut Muis, dkk., (2018) pemimpin menciptakan lingkungan kerja dimana individunya termotivasi, terinspirasi, tertantang, dan merasa berhasil. Sebagai tambahan, dengan kepemimpinan memiliki suara dalam keputusan alokasi sumber daya dan berpengalaman menurunkan kelelahan emosional.

Kepemimpinan adalah aktivitas mempengaruhi individu-individu di dalam organisasi atau perusahaan untuk mencapai tujuan organisasi, tanpa mengabaikan kesejahteraan individu-individu di dalamnya. Perusahaan yang tidak mengharapkan kegagalan untuk mengelola perusahaanya sudah seharunya memperhatikan 
kepemimpinan yang ada (Daulay, dkk 2017). Kepemimpinan spiritual merupakan bentuk kepemimpinan yang masih menjadi perhatian, dimana jenis kepemimpinan ini seorang pemimpin harus mampu menyalurkan visi serta mampu membangun budaya melalui nilai-nilai cinta altruistik terhadap karyawannya. Hal tersebut dilakukan untuk dapat mewujudkan keterikatan dan menghasilkan motivasi yang mampu meningkatkan kesejahteraan karyawan tanpa pengorbanan yang berarti (Bismala, dkk 2017).

Menurut Reave, (2005) kepemimpinan spiritual merupakan suatu fenomena yang terjadi ketika seseorang pemimpin mewujudkan nilai-nilai spiritual seperti integritas, kejujuran, dan rendah hati, membuat dirinya sebagai contoh seseorang yang dapat dipercaya, diandalkan dan dikagumi. Menurut Fry, dkk (2005) kepemimpinan spiritual meliputi memotivasi dan menginspirasi pekerja melalui perantara sebuah visi dan budaya perusahaan berdasarkan pada nilai-niai altruistik/sosial untuk menghasilkan sebuah motivasi yang tinggi, komitmen, dan tenaga kerja yang produktif. Kepemimpinan spiritual mempunyai inti pokok yaitu perasaan keterikatan melalui pekerjaan seseorang dan hubungan sosial selama di tempat kerja.

Tujuan spiritual leadership untuk memotivasi dan memberikan inpirasi pekerja melalui suatu transenden visi dan budaya organisasi berdasarkan nilai altruistik untuk menghasilkan motivasi, komitmen dan produktivitas pekerja yang tinggi. Menurut Fry, dkk (2005) indikator spriritual leadership adalah sebagai berikut: 1) Vision, Merupakan bagian terpenting yang menarik perhatian untuk melihat apa yang di inginkan oleh organisasi dalam jangka pendek dan jangka panjang. 2) Altruistik Love, didefinisikan sebagai perasaan yang utuh, harmonis, kesejahteraan, kepedulian dan apresiasi untuk diri dan sesama. Berdasarkan didefinisi tersebut maka di dalamnya mengandung nilai sabar, ramah, tidak iri hati, rendah hati, pengendalian diri, dipercaya, setia dan kejujuran. 3)Hope/Faith. Hope merupakan keinginan atas sebuah pengharapan yang dipenuhi. Orang yang memiliki kepercayaan atau harapan memiliki tujuan kemana mereka akan pergi, dan bagaimana cara mencapainya, mereka akan dapat menghadapi perlawanan, pertahanan dan penderitaan dalam mencapai tujuan, dan 4) Faith merupakan kepastian dari sesuatu yang diharapkan, sanksi dari sesuatu yang tidak terlihat. Kepercayaan lebih dari sekedar harapan atau sebuah pengharapan atas sesuatu yang di inginkan. Ini merupakan sanksi yang tidak dapat dibuktikan oleh bukti fisik. Kepercayaan atau harapan merupakan dasar dari pendirian visi/tujuan/misi organisasi yang akan dipenuhi.

Faktor lain yang berpengaruh terhadap OCB adalah workplace spirituality (Kazempiour, dkk (2012). Robbins, (2012) mendefinisikan spiritualitas di tempat kerja adalah pengakuan bahwa orang memiliki kehidupan jiwa yang memelihara dan terpelihara oleh sebuah pekerjaan, Hal ini bermakna dalam sebuah konsep keumuman orang. Artinya dalam organisasi dimana pegawai bekerja terdapat budaya spiritualitas yang memiliki nilai kepuasan batin yang tinggi. Dengan kata lain, spiritualitas di tempat kerja menciptakan pegawai yang memaknai pekerjaan lebih dari sekedar tempat mendapatkan penghasilan, akan tetapi lebih kepada sejauh mana pegawai tersebut dapat berkontribusi bagi organisasi sejalan dengan pemebuhan kebutuhan batinnya. Ashmos \& Duchon, (2000) mengatakan bahwa banyak orang di tempat kerja merasa butuh menemukan kembali apa yang mereka rawat dalam hidup ini dan mencoba menemukan pekerjaan yang disukainya. Sedangkan menurut Tanjung (2018) lingkungan kerja yang baik dan menyenangkan akan dapat menimbulkan semangat dan bergairah kerja, dan sebaliknya jika lingkungan kerja yang tidak menyenangkan akan dapat mengurangi semangat dan bergairah kerja.

Spiritualitas di tempat kerja didefinisikan sebagai pengakuan bahwa karyawan mempunyai kehidupan batin supaya dapat menjaga dan memelihara pekerjaan yang berarti di dalam lingkup organisasi (Ashmos \& Duchon, 2000). Menurut Pandey, dkk (2009) spiritualitas di tempat kerja merupakan sarana bagi individu untuk mengintegrasikan pekerjaan dan spiritualitas mereka, yang akan memberi mereka ketepatan, keterhubungan, dan keutuhan di tempat kerja. Ashmos \& Duchon, (2000) menyatakan bahwa spiritualitas di tempat kerja berarti melihat tempat kerja sebagai tempat yang dihuni oleh orang-orang yang memiliki pikiran (mind) dan antusiasme, dan beriman bahwa perkembangan roh sama pentingnya dengan perkembangan pikiran. Spiritualitas di tempat kerja juga termasuk upaya untuk menyelaraskan kepercayaan seseorang dengan nilai organisasi mereka. Sedangkan menurut Ashmos \& Duchon, (2000) menjelaskan bahwa spiritualitas di tempat Kerja adalah salah satu jenis iklim psikologis di mana orang (pekerja) melihat diri mereka sebagai memiliki kehidupan internal yang dirawat oleh pekerjaan yang bermakna dan ditempatkan di konteks suatu komunitas. Unit kerja yang memiliki tingkat kerohanian yang tinggi berarti mengalami iklim, dan dapat diharapkan bahwa unit kerja akan mengalami kinerja yang lebih tinggi. 
Spiritualitas di tempat kerja memiliki manfaat menurut Krishnakumar \& Neck, (2002) diantaranya sebagai berikut: 1) Intuisi dan kreativitas Spiritualitas dapat membantu individu untuk memperluas batas kesadarannya melampaui batas normal, yang menyebabkan meningkatnya intuisi dan kreativitas. Intuisi dan kreativitas bisa menjadi alat yang ampuh dalam pemecahan masalah. 2) Kejujuran dan kepercayaan Kejujuran dan kepercayaan merupakan dua hal yang memilliki peran penting dalam kinerja organisasi untuk kedepannya. Banyak organisasi berbasis spiritual menjadikan kejujuran sebagai fokus utama mereka.3) Pemenuhan pribadi, membina spiritualitas akan menyebabkan karyawan merasa puas atau terpenuhi saat mereka mulai bekerja. Hal tersebut akan menghasilkan tingkat pemenuhan pribadi dan semangat kerja yang tinggi. 4) Komitmen, komitmen mempunyai dua faktor yang berhubungan dengan ekspresi komitmen terhadap sebuah organisasi. Faktor yang pertama yaitu faktor pribadi dimana faktor tersebut merupakan faktor yang berasal dari dalam individu. Faktor yang kedua adalah faktor situasional. 5) Kinerja Organisasi, organisasi yang mendorong spiritualitas dapat mengalami peningkatan kinerja organisasi. Spiritualitas diakui sebagai salah satu dimensi penting kepribadian manusia.

Spiritualitas di tempat kerja menurut Milliaman, dkk (2003) menyebutkan bahwa spiritualitas di tempat kerja mempunyai 3 dimensi antara lain sebagai berikut: 1) Meaningful work (Pekerjaan yang berarti), merupakan sebuah aspek fundamental dari spiritualitas di tempat kerja, terdiri dari memiliki kemampuan untuk merasakan makna terdalam dan tujuan dari pekerjaan seseorang. Dimensi spiritualitas di tempat kerja ini merepresentasikan bagaimana pekerja berinteraksi dengan pekerjaan mereka dari hari ke hari di tingkat individu. 2) Alignment with organizational value (Keselarasan dengan nilai organisasi atau keselarasan antar nilai organisasi dan individu). Merupakan aspek fundamental yang ketiga dari spiritualitas di tempat kerja yang mewakili level organisasi. Aspek ketiga ini menunjukan pengalaman individu yang memiliki keberpihakan kuat antara nilai-nilai pribadi mereka dengan misi dan tujuan organisasi. hal ini berhubungan dengan premis bahwa tujuan organisasi itu lebih besar daripada dirinya sendiri dan seseorang harus memberikan kontribusi kepada komunitas atau pihak lain, dan 3) Community (Komunitas), merupakan dimensi spiritualitas di tempat kerja yang merujuk pada tingkat kelompok dari perilaku manusia serta fokus pada interaksi antar pekerja dan rekan kerja mereka.

Universitas Islam Negeri Sumatera Utara merupakan satu-satunya perguruan tinggi Negeri Islam yang terdapat di Sumatera Utara yang memilki beberapa fakultas dan pegawai. Berdasarkan observasi awal yang penulis lakukan, diketahui pada Universitas Islam Negeri Sumatera Utara terlihat kurangnya kerjasama antar pegawai dalam menyelesaikan pekerjaan dimana pegawai lebih mementingkan pekerjaanya sendiri tanpa kepedulian terhadap rekan kerja lainnya untuk saling membantu menyelesaikan pekerjaan secara sukarela. Hal ini dikarenakan kurang harmonisnya hubungan antara pimpinan dan pegawai, pimpinan tidak memberi perhatian lebih pada arah masa depan organisasi, pimpinan tidak mengajarkan sifat untuk pengendalian diri serta pemberian motivasi pimpinan tidak dilakukan setiap hari sebelum para pegawai melakukan kerja, tidak adanya arahan untuk menciptakan kerja harmonis antara pimpinan dengan pegawai, pegawai dengan pegawai. Selain kurangnya kerjasama antar pegawai di karenakan masih rendahnya persepsi pegawai tentang spiritualitas di tempat bekerja.

Kepemimpinan spiritual merupakan bentuk kepemimpinan yang masih menjadi perhatian, dimana jenis kepemimpinan ini seorang pemimpin harus mampu menyalurkan visi serta mampu membangun budaya melalui nilai-nilai cinta altruistik terhadap karyawannya. Hal tersebut dilakukan untuk dapat mewujudkan keterikatan dan menghasilkan motivasi yang mampu meningkatkan kesejahteraan karyawan tanpa pengorbanan yang berarti.

Kepemimpinan spiritual yang baik melalui visi, harapan / keyakinan dan cinta kepada orang lain membuat pegawai Universitas Islam Negeri Sumatera Utara merasakan kehidupan yang bermakna, hasil karya mereka bahagia dan menciptakan kegembiraan dan komunitas dan berusaha untuk tidak absen dari pekerjaan. Visi universitas membawa hasil yang baik dalam pekerjaan dan lingkungan tempat kerja membuat pertumbuhan semua pekerjaan mereka, (Jufrizen, dkk, 2018) Hasil penelitian terdahulu yang dilakukan oleh (Jufrizen, dkk 2018) menyimpulkan bahwa kepemimpinan spiritual berpengaruh positif dan signifikan terhadap tempat kerja spiritualitas. Selanjutnya menurut hasil penelitian Helmy (2016) menyimpulkan bahwa kepemimpinan spiritual berpengaruh positif terhadap spiritualitas di tempat kerja. Menurut Helmy (2016) semakin tinggi kepemimpinan spiritual maka semakin tinggi pula tingkat OCB. Berdasarkan hasil penelitian terdahulu yang dilakukan oleh Liu (2008) dan Vondey, (2010) menyimpulkan bahwa pemimpin yang spiritual mengedepankan moralitas, kepekaan (sensitivitas), keseimbangan jiwa, kekayaan batin dan etika dalam berinteraksi dengan orang lain. Selanjutnya, menurut hasil penelitian Jufrizen dkk.,( 2018) menyimpulkan bahwa Spiritual Leadership berpengaruh positif dan signifikan terhadap Organization Citizenship

Spiritualitas di tempat kerja dapat diartikan bahwa tempat kerja sebagai tempat perkumpulan orang yang mempunyai kesatuan pemikiran dan semangat serta percaya bahwa meningkatnya kesemangatan merupakan 
inti dari meningkatnya suatu pemikiran. Semakin baik karyawan mampu bersemangat di dalam pekerjaannya maka ide atau pemikiran individu akan lebih baik dan dapat mendorong tercapainya tujuan perusahaan. Spiritualitas di tempat kerja didefinisikan sebagai pengakuan bahwa karyawan mempunyai kehidupan batin supaya dapat menjaga dan memelihara pekerjaan yang berarti di dalam lingkup organisasi (Ashmos \& Duchon, 2000).

Berdasarkan hasil penelitian terdahulu yang dilakukan oleh Rastagar, dkk (2013) yang menemukan bahwa spiritual ditempat kerja mempunyai pengaruh positif terhadap organizational citizenship behavior dan kinerja. Hal yang sama juga sesuai dengan hasil penelitian Kazempiour, dkk (2012). OCB merupakan kontribusi individu yang dalam melebihi tuntutan peran di tempat kerja dan di-reward oleh perolehan kinerja tugas. OCB ini melibatkan beberapa perilaku meliputi perilaku menolong orang lain, menjadi volunteer untuk tugas-tugas ekstra, patuh terhadap aturan-aturan dan prosedur-prosedur di tempat kerja. Oleh karena itu karyawan yang memiliki ikatan batin dan merasa satu visi dengan tempat kerjanya akan memiliki OCB yang tinggi. Sedangkan hasil penelitian Jufrizen, dkk (2018) menyimpulkan bahwa Workplace Spirituality berpengaruh positif dan signifikan terhadap Organization Citizenship.

Organizational Citizenship Behavior (OCB) berpusat kepada perilaku tiap individu yang melaksanakan tugasnya yang melebihi dari deskripsi kerjanya. OCB adalah perilaku karyawan yang melebihi peran yang diwajibkan, yang tidak secara langsung atau eksplisit diakui oleh sistem reward formal. Menurut Djati (2009) memberikan pengertian OCB sebagai bentuk perilaku yang merupakan pilihan dan inisiatif individual untuk meningkatkan efiseinsi kinerja organisasi dengan membantu tujuan dari produktifitas individu pegawai.

Menurut Helmy (2016) semakin tinggi kepemimpinan spiritual akan meningkatkan spiritualitas di tempat kerja dan pada akhirnya akan membuat OCB menjadi lebih baik. Berdasarkan hasil penelitian terdahulu yang dilakukan oleh Dadabhay, (2011) dan Liu (2008) menyimpulkan bahwa kepala sekolah yang memiliki perilaku spiritual terbukti mampu meningkatkan spiritualitas di sekolah. Hal ini berpengaruh positiff terhadap OCB para guru. Hubungan sosial yang dibangun oleh kepala sekolah meningkatkan sense of community (rasa kebersamaan) diantara guru sehingga berpengaruh terhadap meningkatnya OCB.

Berdasarkan hubungan-hubungan dan pengertian yang telah dikemukakan sebelumnya, maka terlihat bahwa Workplace Spirituality, Spiritual Leadership dan Organization Citizenship Behavior saling memiliki hubungan. Maka tujuan penelitian ini adalah untuk mengetahui dan menganalisis pengaruh Spiritual Leadership terhadap Workplace Spirituality dan Organization Citizenship Behavior.

\section{Metode Penelitian}

Jenis penelitian ini adalah penelitian survey, karena mengambil sampel dari satu populasi (Nasution, dkk 2020). Penelitian ini termasuk dalam kategori penelitian kausal dengan menggunakan pendekatan kuantitatif. Populasi dalam penelitian ini adalah seluruh pegawai adminitrasi yang terdapat pada adminitrasi Universitas Islam Sumatera Utara yang berjumlah 197. Berdasarkan perhitungan Slovin diatas maka, jumlah sampel dalam penelitian ini adalah sebanyak 66 orang pegawai adminitrasi pada adminitrasi Universitas Islam Sumatera Utara. Alat pegumpulan data yang digunakan harus sesuai dengan kesahihan (validitas) dan keandalan atau konsistensi (realibilitas). Teknik analisis data dalam penelitian ini menggunakan pendekatan kuantitatif menggunakan analisis statistik dengan menggunkana uji Analisis outer Model, Analisis Inner Model, dan Uji Hipotesis. Pengolahan data dalam penelitian ini menggunakan PLS (Partial Least Square).

\section{Hasil}

\section{Measurement Model Analysis (Outer Model)}

Setelah dilakukan dropping indikator yang tidak lolos pada uji validitas tahap pertama, maka dilakukan uji validitas tahap kedua. Berikut luaran hasil uji validitas tahap kedua. Validitas konvergen berhubungan dengan prinsip bahwa pengukur-pengukur (manifest variable) dari suatu konstruk seharusnya berkorelasi tinggi, validitas konvergen dinilai berdasarkan loading factor serta nilai Average Variance Extracted (AVE). Rule of thumb yang digunakan dalam uji validitas konvergen adalah nilai loading factor $>0,5$ serta nilai AVE $>0,5$ (Ghozali \& Latan, 2014). Hasil AVE disajikan pada tabel 1 dan hasil outer loading pada Tabel 2 berikut ini: 
Tabel 1. Hasil AVE (Average Variant Extracted)

\begin{tabular}{ccc}
\hline Variabel / Konstruk & AVE & Hasil Uji \\
\hline Spiritual Leadership $(\mathrm{X})$ & 0.641 & Valid \\
Workplace Spirituality $(\mathrm{Z})$ & 0.624 & Valid \\
Organization Citizenship Behavior $(\mathrm{Y})$ & 0.674 & Valid \\
\hline
\end{tabular}

Sumber : Data Diolah (2021)

Berdasarkan tabel di atas diketahui bahwa nilai AVE setiap variabel adalah lebih besar dari 0,5. Sehingga dapat disimpulkan bahwa variabel atau konstruk yang digunakan adalah valid.

Tabel 2. Hasil Outer Loading

\begin{tabular}{|c|c|c|c|c|c|}
\hline No. & Butir Pernyataan & $X$ & Z & $Y$ & Hasil Uji \\
\hline \multicolumn{6}{|c|}{ Spiritual Leadership (X) } \\
\hline 1. & $\mathrm{X} 1.1$ & 0,778 & & & Valid \\
\hline 2. & $\mathrm{X} 1.2$ & 0,789 & & & Valid \\
\hline 3. & $\mathrm{X} 1.3$ & 0,743 & & & Valid \\
\hline 4. & $\mathrm{X} 1.4$ & 0,707 & & & Valid \\
\hline 5. & $\mathrm{X} 1.5$ & 0,899 & & & Valid \\
\hline 6. & $\mathrm{X} 1.6$ & 0,794 & & & Valid \\
\hline 7 & $\mathrm{X} 1.7$ & 0,792 & & & Valid \\
\hline 8 & $\mathrm{X} 1.8$ & 0,886 & & & Valid \\
\hline \multicolumn{6}{|c|}{ Workplace Spirituality (Z) } \\
\hline 1. & $\mathrm{Z1.2}$ & & 0,780 & & Valid \\
\hline 2. & Z1.3 & & 0,774 & & Valid \\
\hline 3. & Z1.4 & & 0,873 & & Valid \\
\hline 4. & $\mathrm{Z1.5}$ & & 0,852 & & Valid \\
\hline \multicolumn{6}{|c|}{ Organization Citizenship Behavior $(\mathrm{Y})$} \\
\hline 1. & Y1.1 & & & 0,758 & Valid \\
\hline 2. & Y1.2 & & & 0,692 & Valid \\
\hline 3. & Y1.3 & & & 0,827 & Valid \\
\hline 4. & Y1.4 & & & 0,746 & Valid \\
\hline 5. & Y1.5 & & & 0,823 & Valid \\
\hline 6. & Y1.6 & & & 0,826 & Valid \\
\hline 7. & Y1.7 & & & 0,844 & Valid \\
\hline 8 & Y1.8 & & & 0,733 & Valid \\
\hline 9 & Y1.12 & & & 0,816 & Valid \\
\hline 10 & Y1.13 & & & 0,841 & Valid \\
\hline 11 & Y1.14 & & & 0,766 & Valid \\
\hline
\end{tabular}

Sumber : Data Diolah (2021)

Berdasarkan tabel 2, diketahui bahwa nilai outer loading pada setiap indikator adalah lebih dari 0,5. Sehingga dapat disimpulkan bahwa variabel dan indikator yang digunakan dalam penelitian adalah valid.

Validitas Diskriminan berhubungan dengan prinsip bahwa pengukur-pengukur (manifest variable) konstruk yang berbeda seharusnya tidak berkorelasi tinggi, validitas diskriminan dinilai berdasarkan dinilai berdasarkan cross loading. Rule of thumb yang digunakan dalam uji validitas diskriminan adalah nilai cross loading lebih besar dari 0,7. Jika korelasi konstruk dengan item pengukuran lebih besar dari pada ukuran konstruk lainnya, maka menunjukkan ukuran blok mereka lebih baik dibandingkan dengan blok lainnya (Ghozali \& Latan, 2014). Hasil uji validitas diskriminan disajikan pada Tabel 3 berikut ini:

Tabel 3. Hasil Cross Loading

\begin{tabular}{cccccc} 
No. & Butir Pernyataan & $\mathrm{X}$ & $\mathrm{Z}$ & $\mathrm{Y}$ & Hasil Uji \\
Spiritual Leadership (X) & & & & & \\
1. & $\mathrm{X} 1.1$ & 0,778 & 0,644 & 0,657 & Valid \\
2. & $\mathrm{X} 1.2$ & 0,789 & 0,530 & 0,611 & Valid \\
3. & $\mathrm{X} 1.3$ & 0,743 & 0,517 & 0,678 & Valid \\
\hline
\end{tabular}




\begin{tabular}{cccccc} 
No. & Butir Pernyataan & $\mathrm{X}$ & $\mathrm{Z}$ & $\mathrm{Y}$ & Hasil Uji \\
\hline 4. & $\mathrm{X} 1.4$ & 0,707 & 0,682 & 0,693 & Valid \\
5. & $\mathrm{X} 1.5$ & 0,899 & 0,732 & 0,774 & Valid \\
6. & $\mathrm{X} 1.6$ & 0,794 & 0,600 & 0,658 & Valid \\
7 & $\mathrm{X} 1.7$ & 0,792 & 0,491 & 0,619 & Valid \\
8 & $\mathrm{X} 1.8$ & 0,886 & 0,587 & 0,749 & Valid \\
Workplace Spirituality (Z) & & & & & \\
1. & $\mathrm{Z1.2}$ & 0,633 & 0,780 & 0,698 & Valid \\
2. & $\mathrm{Z1.3}$ & 0,531 & 0,774 & 0,559 & Valid \\
3. & $\mathrm{Z1.4}$ & 0,710 & 0,873 & 0,816 & Valid \\
4. & $\mathrm{Z1} .5$ & 0,583 & 0,852 & 0,741 & Valid \\
Organization Citizenship Behavior(Y) & & & & \\
1. & $\mathrm{Y} 1.1$ & 0,714 & 0,762 & 0,758 & Valid \\
2. & $\mathrm{Y} 1.2$ & 0,754 & 0,496 & 0,692 & Valid \\
3. & $\mathrm{Y} 1.3$ & 0,660 & 0,827 & 0,827 & Valid \\
4. & $\mathrm{Y} 1.4$ & 0,589 & 0,841 & 0,746 & Valid \\
5. & $\mathrm{Y} 1.5$ & 0,636 & 0,794 & 0,823 & Valid \\
6. & $\mathrm{Y} 1.6$ & 0,592 & 0,743 & 0,826 & Valid \\
7. & $\mathrm{Y} 1.7$ & 0,749 & 0,668 & 0,844 & Valid \\
8 & $\mathrm{Y} 1.8$ & 0,678 & 0,450 & 0,733 & Valid \\
9 & $\mathrm{Y} 1.12$ & 0,629 & 0,704 & 0,816 & Valid \\
10 & $\mathrm{Y} 1.13$ & 0,711 & 0,637 & 0,841 & Valid \\
11 & $\mathrm{Y} 1.14$ & 0,728 & 0,504 & 0,766 & Valid \\
\hline
\end{tabular}

Sumber : Data Diolah (2021)

Berdasarkan sajian data pada tabel 3 , dapat diketahui bahwa masing-masing indikator pada variabel penelitian memiliki nilai cross loading lebih tinggi pada variabel yang dibentuknya dibandingkan dengan nilai cross loading pada variabel lainnya. Berdasarkan hasil yang diperoleh tersebut, dapat dinyatakan bahwa indikator-indikator yang digunakan dalam penelitian ini telah memiliki discriminant validity yang baik dalam menyusun variabelnya masing-masing.

Uji reliabilitas untuk mengukur konsistensi internal alat ukur. Reliabilitas menunjukkan akurasi, konsistensi, dan ketepatan suatu alat ukur dalam melakukan pengukuran. Uji reliabilitas dalam PLS dapat mennggunakan dua metode yaitu cronbach's alpha dan composite reliability. Cronbach's alpha mengukur batas bawah nilai reliabilitas suatu konstruk sedangkan composite reliability mengukur nilai sesungguhnya reliabilitas suatu konstruk. Rule of thumb yang digunakan untuk nilai composite reliability lebih besar dari 0,6 serta nilai cronbach's alpha lebih besar dari 0,6. Dengan pengukuran tersebut apabila nilai yang dicapai adalah $>0,60$ maka dapat dikatakan bahwa konstruk tersebut memiliki reliabilitas yang tinggi. Hasil uji reabilitas kedua metode dapat dilihat pada tabel berikut ini :

Tabel 4. Hasil Uji Reabilitas

\begin{tabular}{cccc}
\hline Variabel / Konstruk & Cronbach's Alpha & Composite Reliability & Hasil Uji \\
Spiritual Leadership $(\mathrm{X})$ & $\mathbf{0 . 9 1 9}$ & 0,60 & Reliabel \\
Workplace Spirituality (Z) & $\mathbf{0 . 8 3 8}$ & 0,60 & Reliabel \\
Organization Citizenship Behavior $(\mathrm{Y})$ & $\mathbf{0 . 9 3 9}$ & 0,60 & Reliabel \\
\hline
\end{tabular}

Sumber : Data Diolah, 2021

Berdasarkan sajian data pada tabel 4, dapat diketahui bahwa masing-masing variabel penelitian memiliki nilai cronbach's alpha dan composite reliability $>0,60$. Berdasarkan hasil yang diperoleh tersebut, dapat dinyatakan bahwa variabel yang digunakan dalam penelitian dinyatakan reliabel. 


\section{Analisis Inner Model}

F-Square adalah ukuran yang digunakan untuk menilai dampak relatif dari suatu variabel yang mempengaruhi (eksogen) terhadap variabel yang dipengaruhi (endogen). Kriteria penarikan kesimpulan adalah jika nilai $F^{2}$ sebesar 0,02 maka terdapat efek yang kecil (lemah) dari variabel eksogen terhadap endogen, nilai $\mathrm{F}^{2}$ sebesar 0,15 maka terdapat efek yang moderat (sedang) dari variabel eksogen terhadap endogen, nilai $\mathrm{F}^{2}$ sebesar 0,35 maka terdapat efek yang besar (baik) dari variabel eksogem terhadap endogen (Juliandi, 2018). Berdasarkan pengolahan data yang telah dilakukan diperoleh nilai $F$-Square yang dapat dilihat pada gambar dan tabel berikut:

Tabel 5. Nilai F-Square

\begin{tabular}{lc}
\multicolumn{1}{c}{ Variabel } & F-Square \\
\hline Spiritual Leadership $\rightarrow$ Organization Citizenship Behavior & 0,854 \\
Spiritual Leadership $\rightarrow$ Organization Citizenship Behavior dimediasi oleh Workplace Spirituality & 0,390 \\
Workplace Spirituality $\rightarrow$ Organization Citizenship Behavior & 0,755 \\
Spiritual Leadership $\rightarrow$ Workplace Spirituality & 0,517 \\
\hline
\end{tabular}

Sumber : Data Diolah, 2021

Berdasarkan tabel 5, diketahui bahwa Pengaruh Spiritual Leadership $(X)$ terhadap Organization Citizenship Behavior ( $\mathrm{Y}$ ) memiliki nilai $\mathrm{F}^{2}$ sebesar 0,854 mengindikasikan bahwa terdapat efek yang besar (baik). Pengaruh Spiritual Leadership $(\mathrm{X})$ terhadap Organization Citizenship Behavior $(\mathrm{Y})$ dimediasi oleh Workplace Spirituality (Z) memiliki nilai $\mathrm{F}^{2}$ sebesar 0,390 mengindikasikan bahwa terdapat efek yang besar (baik). Pengaruh Workplace Spirituality (Z) terhadap Organization Citizenship Behavior (Y) memiliki nilai $\mathrm{F}^{2}$ sebesar 0,755 mengindikasikan bahwa terdapat efek yang besar (baik). Pengaruh Spiritual Leadership $(X)$ terhadap Workplace Spirituality (Z) memiliki nilai $\mathrm{F}^{2}$ sebesar 0,517 mengindikasikan bahwa terdapat efek yang besar (baik).

\section{Uji Koefisien Determinasi (R-Square)}

$R$-square adalah ukuran proporsi variasi nilai yang dipengaruhi (endogen) yang dapat dijelaskan oleh variabel yang mempengaruhinya (eksogen) ini berguna untuk memprediksi apakah model adalah baik/buruk. Hasil $r$ square untuk variabel laten endogen sebesar 0,75 mengindikasikan bahwa model tersebut adalah substansial (baik); 0,50 mengindikasikan bahwa model tersebut adalah moderat (sedang) dan 0,25 mengindikasikan bahwa model tersebut adalah lemah (buruk) (Juliandi, 2018). Berdasarkan pengolahan data yang telah dilakukan dengan menggunakan program smartPLS 3.0, diperoleh nilai $R$-Square yang dapat dilihat pada gambar dan tabel berikut:

Tabel 6. Hasil Uji R-Square

\begin{tabular}{ccc} 
& R Square & R Square Adjusted \\
\hline $\mathrm{Y}$ & 0.845 & 0.840 \\
\hline
\end{tabular}

Sumber : Data Diolah, 2021

Dari tabel 6, diketahui bahwa pengaruh $X$ dan $Z$ terhadap $Y$ dengan nilai $r$-square 0,845 mengindikasikan bahwa variasi nilai $Y$ mampu dijelaskan oleh variasi nilai $X$ dan $Z$ sebesar $84.5 \%$ atau dengan kata lain bahwa model tersebut adalah substansial (baik), dan $15.5 \%$ dipengaruhi oleh variabel lain.

\section{Pengujian Hipotesis}

Pengujian ini adalah untuk menentukan koefisien jalur dari model struktural. Tujuannya adalah menguji signifikansi semua hubungan atau pengujian hipotesis. Pengujian hipotesis dalam penelitian ini dibagi menjadi pengaruh langsung dan pengaruh tidak langsung. Hasil uji hipotesis pengaruh langsung dapat dilihat pada tabel path coefficient berikut ini:

Tabel 7. Path Coefficient

\begin{tabular}{|c|c|c|c|c|c|}
\hline & $\begin{array}{c}\text { Original Sample } \\
(0)\end{array}$ & $\begin{array}{c}\text { Sample } \\
\text { Mean (M) }\end{array}$ & $\begin{array}{l}\text { Standard Error } \\
\text { (STERR) }\end{array}$ & $\begin{array}{l}\text { T Statistics } \\
\text { (|O/STERR|) }\end{array}$ & P Values \\
\hline$X \rightarrow Y$ & 0,464 & 0,461 & 0,074 & 6,235 & 0.000 \\
\hline$X->Z$ & 0,755 & 0,750 & 0,092 & 8,228 & 0.000 \\
\hline$Z->Y$ & 0,517 & 0,516 & 0,078 & 6,653 & 0.000 \\
\hline
\end{tabular}

Sumber : Data Diolah (2021) 
Berdasarkan Tabel 7, dapat diketahui bahwa pengaruh Spiritual Leadership terhadap Workplace Spirituality mempunyai koefisien jalur sebesar 0,755 . Pengaruh tersebut mempunyai nilai probabilitas ( $p$-values) sebesar $0,000<0,05$, berarti spritual leadership berpengaruh terhadap Workplace Spirituality pada Pegawai Adminitrasi Universitas Islam Sumatera Utara.

Selanjutnya, pengaruh Spiritual Leadership terhadap Organization Citizenship Behavior mempunyai koefisien jalur sebesar 0,464 . Pengaruh tersebut mempunyai nilai probabilitas ( $p$-values) sebesar $0,000<0,05$, berarti spritual leadership berpengaruh terhadap Organization Citizenship Behavior pada Pegawai Adminitrasi Universitas Islam Sumatera Utara.

Terakhir yaitu pengaruh Workplace Spirituality terhadap Organization Citizenship Behavior mempunyai koefisien jalur sebesar 0,517 . Pengaruh tersebut mempunyai nilai probabilitas ( $p$-values) sebesar $0,000<0,05$, berarti Workplace Spirituality berpengaruh terhadap Organization Citizenship Behavior pada Pegawai Adminitrasi Universitas Islam Sumatera Utara.

Adapun pengaruh tidak langsung diantara variabel bebas dan variabel terikat pada penelitian ini dapat dikemukakan adalah sebagai berikut :

Tabel 8. Specific Indirect Effects

\begin{tabular}{llrlrrr} 
& $\begin{array}{l}\text { Original } \\
\text { Sample (O) }\end{array}$ & $\begin{array}{l}\text { Sample } \\
\text { Mean (M) }\end{array}$ & $\begin{array}{l}\text { Standard } \\
\text { Deviation } \\
\text { (STDEV) }\end{array}$ & $\begin{array}{l}\text { T Statistics } \\
\text { (|O/STDEVI) }\end{array}$ & P Values \\
\hline $\mathrm{X}>\mathrm{Z}>\mathrm{Z}>\mathrm{Y}$ & 0.390 & 0.385 & & 0.070 & 5.589 & 0.000 \\
\hline
\end{tabular}

Sumber : Data Diolah (2021)

Berdasarkan Tabel 8, dapat dinyatakan bahwa pengujian hipotesis ke-4 $(\mathrm{H} 4)$ adalah pengaruh spritual leadership terhadap Organization Citizenship Behavior melalui Workplace Spirituality mempunyai koefisien jalur sebesar 0,390 . Pengaruh tersebut mempunyai nilai probabilitas ( $p$-values) sebesar $0,000<0,05$, berarti dapat disimpulkan bahwa spritual leadership berpengaruh terhadap Organization Citizenship Behavior dimediasi oleh Workplace Spirituality pada Pegawai Adminitrasi Universitas Islam Sumatera Utara.

\section{Pembahasan}

Hasil pengujian dari seluruh variabel dapat disimpulkan bahwa tidak semua variabel bebas berpengaruh pada variabel terikat, namun secara umum penelitian ini menunjukkan hasil yang cukup memuaskan. Hal ini dapat ditunjukkan dan banyaknya tanggapan kesejutuan yang tinggi dari responden.

\section{Pengaruh Pengaruh Spritual Leadership Terhadap Organization Citizenship Behavior}

Adanya pengaruh yang positif antara Spritual Leadership Terhadap Organization Citizenship Behavior yang ditunjukkan dengan nilai t sebesar 6.235 dan nilai koefisien jalur sebesar 0,464 dengan signifikan sebesar 0,000 (Sig.0,000<á0,05) sehingga HO ditolak (Ha diterima). Dengan demikian spiritual leadership berpengaruh signifikan terhadap Organization Citizenship Behavior pada Pegawai Adminitrasi Universitas Islam Sumatera Utara. Koefisien jalur yang bernilai positif menunjukkan bahwa semakin tinggi kepemimpinan spiritual maka semakin tinggi pula tingkat OCB. Hal ini berarti bahwa OCB pegawai akan meningkat apabila pemimpin/pimpinan mempunyai visi, ramah, jujur, memiliki kepercayaan kepada bawahan, memberikan pengarahan dalam bekerja dan memberikan perhatian kepada pegawai.

Menurut Fry, dkk (2005) kepemimpinan spiritual meliputi memotivasi dan menginspirasi pekerja melalui perantara sebuah visi dan budaya perusahaan berdasarkan pada nilai-niai altruistik/sosial untuk menghasilkan sebuah motivasi yang tinggi, komitmen, dan tenaga kerja yang produktif. Kepemimpinan spiritual mempunyai inti pokok yaitu perasaan keterikatan melalui pekerjaan seseorang dan hubungan sosial selama di tempat kerja. Hasil penelitian ini sejalan dengan hasil penelitian terdahulu yang dilakukan oleh Jufrizen, dkk (2018) menyimpulkan bahwa Spiritual Leadership berpengaruh positif dan signifikan terhadap Organization Citizenship. Sedangkan berdasarkan hasil penelitian terdahulu yang dilakukan oleh Liu (2008) dan Vondey (2010) menyimpulkan bahwa pemimpin yang spiritual mengedepankan moralitas, kepekaan (sensitivitas), keseimbangan jiwa, kekayaan batin dan etika dalam berinteraksi dengan orang lain. 


\section{Pengaruh Spritual Leadership Terhadap Workplace Spirituality}

Adapun pengaruh yang negatif antara variabel spritual leadership $(X)$ terhadap workplace spirituality $(Z)$ yang ditunjukkan dengan nilai t sebesar 8,228 dan nilai koefisien jalur sebesar 0,755 serta berpengaruh signifikan sebesar 0,000 (sig. $0,000<0,05$ ) sehingga HO ditolak ( $\mathrm{Ha}$ diterima). Dengan demikian spiritual leadership berpengaruh signifikan terhadap workplace spirituality Pegawai Adminitrasi Universitas Islam Sumatera Utara. Koefisien jalur yang bernilai positif menunjukkan bahwa semakin tinggi spiritual leadership maka semakin tinggi pula workplace spirituality pegawai atau dengan kata lain, semakin baik spiritual leadership semakin tinggi tingkat workplace spirituality pegawai Universitas Islam Negeri Sumatera Utara. Kepemimpinan spiritual yang baik melalui visi, harapan / keyakinan dan cinta kepada orang lain membuat pegawai Universitas Islam Negeri Sumatera Utara merasakan kehidupan yang bermakna, hasil karya mereka bahagia dan menciptakan kegembiraan dan komunitas dan berusaha untuk tidak absen dari pekerjaan. Dengan kepemimpinan spiritual yang baik akan mampu menciptakan nilai-nilai moral yang baik, menciptakan kejujuran dan integritas dalam bekerja sehingga pegawai mampu berdaptasi dengan lingkungan kerja yang suka tolong menolong.

Menurut Reave, (2005) kepemimpinan spiritual merupakan suatu fenomena yang terjadi ketika seseorang pemimpin mewujudkan nilai-nilai spiritual seperti integritas, kejujuran, dan rendah hati, membuat dirinya sebagai contoh seseorang yang dapat dipercaya, diandalkan dan dikagumi. Hasil penelitian ini sejalan dengan hasil penelitian terdahulu yang dilakukan oleh (Jufrizen, dkk 2018) menyimpulkan bahwa kepemimpinan spiritual berpengaruh positif dan signifikan terhadap tempat kerja spiritualitas. Selanjutnya menurut hasil penelitian terdahulu yang dilakukan oleh Helmy (2016) menyimpulkan bahwa kepemimpinan spiritual berpengaruh positif terhadap spiritualitas di tempat kerja.

\section{Pengaruh Workplace Spirituality Terhadap Organization Citizenship Behavior}

Adanya pengaruh yang antara Workplace Spirituality Terhadap Organization Citizenship Behavior yang ditunjukkan dengan nilai t sebesar 6,653 dan nilai koefisien jalur sebesar 0,517 dengan signifikan sebesar 0,000 (Sig.0,006<á0,05) sehingga H0 ditolak (Ha diterima). Dengan demikian Workplace Spirituality berpengaruh signifikan terhadap Organization Citizenship Behavior Pegawai Adminitrasi Universitas Islam Sumatera Utara. Koefisien jalur yang bernilai positif menunjukkan bahwa semakin tinggi Workplace Spirituality maka semakin tinggi pula Organization Citizenship Behavior pegawai. Dalam hal ini pegawai merasa tempat kerjanya seperti sebuah keluarga di mana memiliki kesamaan visi dan misi sehingga karyawan mau melakukan kerja ekstra seperti bekerjasama dalam tim, aktif berpartisi aktif dalam kegiatan-kegiatan social dalam organisasi dan merasakan arti pentingnya pekerjaan bagi kehidupan keseharian mereka. Semakin baik pegawai dan bersemangat di dalam pekerjaannya maka ide atau pemikiran individu akan lebih baik dan dapat mendorong tercapainya tujuan. Hasil penelitian ini sejalan dengan hasil penelitian terdahulu yang dilakukan oleh Jufrizen, dkk (2018) menyimpulkan bahwa Workplace Spirituality berpengaruh positif dan signifikan terhadap Organization Citizenship.

Berdasarkan hasil penelitian terdahulu yang dilakukan oleh Rastagar, dkk (2013) yang menemukan bahwa spiritual ditempat kerja mempunyai pengaruh positif terhadap organizational citizenship behavior dan kinerja. Hal yang sama juga sesuai dengan hasil penelitian Kazempiour, dkk (2012). OCB merupakan kontribusi individu yang dalam melebihi tuntutan peran di tempat kerja dan di-reward oleh perolehan kinerja tugas. OCB ini melibatkan beberapa perilaku meliputi perilaku menolong orang lain, menjadi volunteer untuk tugas-tugas ekstra, patuh terhadap aturan-aturan dan prosedur-prosedur di tempat kerja. Oleh karena itu karyawan yang memiliki ikatan batin dan merasa satu visi dengan tempat kerjanya akan memiliki OCB yang tinggi.

\section{Pengaruh Spiritual Leadership terhadap Organization Citizenship Behavior dimediasi oleh Workplace Spirituality}

Dari hasil penelitian yang dilakukan terdapat pengaruh tidak langsung Spiritual Leadership terhadap Organization Citizenship Behavior melalui Workplace Spirituality adalah berpengaruh dengan nilai t sebesar 5,589 dan nilai koefisien jalur sebesar 0,390 dengan signifikan sebesar 0,000 (Sig.0,000<á0,05) sehingga HO ditolak (Ha diterima). Hal ini menunjukkan bahwa Workplace Spirituality memediasi secara penuh (full mediation) pada pengaruh Spiritual Leadership terhadap Organization Citizenship Behavior.

Menurut Helmy (2016) semakin tinggi kepemimpinan spiritual akan meningkatkan spiritualitas di tempat kerja dan pada akhirnya akan membuat OCB menjadi lebih baik. Berdasarkan hasil penelitian terdahulu yang dilakukan oleh Dadabhay, (2011) dan Liu, (2008) menyimpulkan bahwa kepemimpinan perilaku spiritual terbukti mampu meningkatkan spiritualitas di tempat kerja. Hal ini berpengaruh posititf terhadap OCB para guru. 
Hubungan sosial yang dibangun oleh pemimpin meningkatkan sense of community (rasa kebersamaan) sehingga berpengaruh terhadap meningkatnya OCB.

\section{Kesimpulan}

Berdasarkan hasil penelitian dan pembahasan yang telah dikemukakan sebelumnya maka dapat diambil kesimpulan dari penelitian mengenai Peran Mediasi Workplace Spirituality pada Pengaruh Spiritual Leadership Terhadap Organization Citizenship Behavior Pada Pegawai Adminitrasi Di Universitas Islam Negeri Sumatera Utara adalah : Secara langsung Spiritual Leadership berpengaruh signifikan terhadap Organization Citizenship Behavior pada pegawai adminitrasi Universitas Islam Negeri Sumatera Utara. Secara langsung Spiritual Leadership berpengaruh signifikan terhadap Workplace Spirituality pada pegawai adminitrasi Universitas Islam Negeri Sumatera Utara. Secara langsung Workplace Spirituality berpengaruh signifikan terhadap Organization Citizenship Behavior pada pegawai adminitrasi Universitas Islam Negeri Sumatera Utara. Spiritual Leadership berpengaruh signifikan terhadap Organization Citizenship Behavior dimediasi oleh Workplace Spirituality pada pegawai adminitrasi Universitas Islam Negeri Sumatera Utara.

Berdasarkan kesimpulan, maka dalam hal ini penulis dapat menyarankan hal-hal sebagai berikut : Berkaitan dengan variabel spiritual leadership harus membangun cinta sesama dengan indikator tidak menghukum kesalahan bila jujur sehingga para bawahan atau pegawai bekerja dengan nyaman dan penuh dengan kejujuran sehingga akan meningkatan Organization Citizenship Behavior pegawai. Berkaitan dengan variabel workplace spirituality harus membangun bellongin in the community dengan indikator mendorong pertumbuhan kepribadian sehingga akan membuat pegawai merasa berubah dan berkontribusi pada organisasi. Pimpinan perlu meningkatkan ikatan bersama dan rasa saling memiliki antara atasan dan bawahanya dan antar rekan kerja diantaranya melakukan kegiatan bersama, melakukan kebiasaan-kebiasaan yang menimbulkan rasa senang dan bangga pada organisasi misal : kegiatan olahraga bersama, pelatihan outdoor, kegiatan coffee morning dengan atasan sebagai media brainstorming sehingga dapat mengeratkan hubungan secara emosional antar atasan bawahan dan antar rekan kerja yang pada akhirnya meningkatkan perilaku courtesy, altruism, civic virtue, sportmanship dan conscienthousness yang merupakan dimensi dari OCB.

Penelitian ini terbatas menggunakan dua variabel yang mempengaruhi mempengaruhi organizational citizenship behaviour yaitu spiritual leadership dan workplace spirituality, sedangkan masih terdapat sejumlah variabel yang juga mempengaruhi perilaku OCB yang tidak digunakan dalam penelitian, yang tentunya akan mempengaruhi akurasi hasil yang ditemukan. Bagi peneliti yang ingin meneliti kembali tentang organizational citizenship behavior dan subjek yang sama, diharapkan menggunakan variabel independent yang lain, sehingga akan muncul penemuan-penemuan baru dalam penelitian kedepannya.

\section{Daftar Pustaka}

Adhiyana, M. (1010). Dimensi Organizational Citizenship Behavior (OCB) Dalam Kinerja Organisasi. Efisiensi :Kajian IImu Administrasi, 10(2), 521-535.

Aldag, R., \& Reschake, W. (1997). Employee Value Added: Measuring Disceretionary Effort And Its Value To The Organization. Center For Organization Effectiveness, 4(2), 50-63.

Arianty, N. (2015). Pengaruh Pelimpahan Wewenang dan Koordinasi Kerja Terhadap Pengambilan Keputusan di Perusahaan Asuransi Di Kota Medan. Jurnal Manajemen Tools, 4(2), 80-91.

Ashmos, D. P., \& Duchon, D. (2000). Spirituality At Work: A Conceptualization And Measure. Journal of Management Inquiry, 9(2), 134-144.

Bismala, L., Arianty, N., \& Farida, T. (2017). Prilaku Organisasi. Medan: Lembaga Penelitian dan Penulisan IImiah AQLI.

Dadabhay, M. (2011). The Mediating Role Of Workplace Spirituality On Perceptions Of Transformational Leadership, Organisational Commitment And Employee Job Satisfaction Within A Sample Of South African Muslim School Teachers. University Of the Witwatersrand.

Daulay, R., Khair, H., Pratami, L., \& Astuti, R. (2017). Manajamen. (Yati, Ed.). Medan: Lembaga Peneitian Dan Penulisan IImiah Aqli.

Djati, S. P. (2009). Pengaruh Moral dan Komitmen Staf Administrasi Terhadap Organizational Citizenship Behaviour dan Pengaruhnya Terhadap Kinerja Service Quality di Universitas Swasta Surabaya Indonesia. 
Jurnal Aplikasi Manajemen, 7(3), 56-72.

Elizar, E., \& Tanjung, H. (2018). Pengaruh Pelatihan, Kompetensi, Lingkungan Kerja terhadap Kinerja Pegawai. Maneggio: Jurnal Ilmiah Magister Manajemen, 1(1), 46-58.

Fry, L. W., Vitucci, S., \& Cedillo, M. (2005). Spiritual Leadership And Army Transformation: Theory, Measurement, And Establishing A Baseline. Leadership Quartely, 16(5), 835-862.

Ghozali, I., \& Latan, H. (2014). Partial Least Squares Konsep, Metode dan Aplikasi Menggunakan Program WARPPLS 4.0. Semarang: Badan Penerbit Universitas Deponegoro.

Helmy, I. (2016). Pengaruh Spiritual Leadership dan Emotional Intelligence Terhadap Organizational Citizenship Behaviour dengan Workplace Spirituality Sebagai Variabel Intervening. Jurnal Bisnis Dan Manajemen, $4(1), 72-80$.

Jufrizen, J., Sari, M., Nasution, M. I., Akrim, A., \& Fahmi, M. (2018). Spiritual Leadership And Workplace Spirituality: The Role Of Organizational Commitment. Proceeding Of The 1st International Conference On Economics Managemnet Accounting And Business (ICEMAB), 1-7.

Juliandi, A. (2018). Structural equation model based partial least square SEM-PLS Menggunakan SmartPLS. Batam.

Kazempiour, Farahnaz, B. S., Amin, S. M., \& Pourseidi, B. (2012). Relationship Between Workplace Spirituality And Organizational Citizenship Behavior Among Nurses Through Mediation Of Affective Organizational Commitment. Journal of Nursing Scholarship, 44(33), 1-11.

Krishnakumar, S., \& Neck, C. P. (2002). The "what", "why", and "how" of spirituality in the workplace. Journal Of Organizational Chage Management, 17(3), 153-164.

Liu, H. (2008). Transcendental leadership and organizational citizenship behavior: the mediating effect of spirituality in the workplace. Requirements for public administration degree, 1(1), 1-11.

Milliaman, J., Czaplewski, A. J., \& Fergouson, J. (2003). Workplace spirituality and employee work attitudes an exploratory empirical assessment. Journal Of Organizational Chage Management, 16(4), 426-447.

Muis, M. R., Nasution, M. I., Azhar, M. E., \& Radiman, R. (2018). Pengaruh kepemimpinan dan self efficacy terhadap kelelahan emosional serta dampaknya terhadap kepuasan kerja dosen. Jurnal Riset Sains Manajemen, 2(3), 131-142.

Nasution, M. I., Fahmi, M., Jufrizen, J., Muslih, M., \& Prayogi, M. A. (2020). The Quality of Small and Medium Enterprises Performance Using the Structural Equation Model-Part Least Square (SEM-PLS). Journal of Physics: Conference Series, 1477(2020), 1-7.

Nooralizad, R., Nadeholi, G., \& Parivash, J. (2011). A causal model depicting the influence of spiritual leadership and some organization and individual variables on workplace spirituality. Journal of Advance in Management, 4(5), 90-99.

Novaliadi, F. (2007). Organizational Citizenship Behaviour Karyawan Ditinjau dari Persepsi Terhadap Kualitas Interaksi Atasan-Bawahan Dan Persepsi Terhadap Dukungan Organisasional. Jurnal IImiah Manajemen, $4(5), 90-99$.

Nurcahyo, R. J. (2012). Pengaruh Kepemimpinan, Kepuasan Kerja Dan Komitmen Organisasional Terhadap Organizational Citizenship Behavior (OCB) Perawat RSD Panembahan Senopati Bantul. Sinergi: Kajian Bisnis dan Manajemen, 3(1), 41-55.

Organ, D. W., Podsakoff, P. M., \& MacKenzie, S. B. (2006). Organizational Citizenship Behavior: Its Nature, Antecedents, and Consequences. Thousand Oaks, California: SAGE Publications, Inc.

Pandey, A., Gupta, R. K., \& Arora, A. P. (2009). Spiritual Climate of Business Organizations and Its Impact on Customers' Experience. Journal of Business Ethics, 88(1), 313-332.

Podsakoff, P. M., MacKenzie, S. B., Paine, J. B., \& Bacharch, D. G. (2006). Organizational citizenship behaviors: a critical review of the theoretical and empirical literature and suggestions for future research. Journal of Management, 26(3), 513-523.

Rastagar, Abbas, A., \& Nina, P. (2013). A Study of The Relationship Between Organizational Justice and Turnover Intentions: Evidence from Iran. International Journal of Research in Organizational Behavior and Human Resource Management, 1(2), 1-10.

Reave, L. (2005). Spiritual values and practices related to leadership effectiveness. Leadership Quartely, 16(5), 655-687.

Robbins, S. P. (2012). Perilaku Organisasi. Jakarta: PT. Indeks Kelompok Gramedia.

Setiani, T. I., \& Hidayat, A. S. (2020). Pengaruh Kepemimpinan Dan Kepuasan Kerja Terhadap Organizational Citizenship Behavior (OCB) pada Perusahaan Daerah Air Minum. Forum Ekonomi, 22(1), 123-129.

Thayib, C. B., Sulasmi, S., \& Eliyana, A. (2013). Pengaruh spiritual leadership, stres kerja, dan kompensasi 
terhadap kepuasan dan prestasi kerja social worker organisasi sosial di surabaya. Jurnal Bimbingan Dan Konseling Islam, 3(1), 1-16.

Vondey, M. (2010). The relationships among servant leadership, organizational citizenship behavior, personorganization fit, and organizational identification. International Journal of Leadership Studies, 6(1), 1-13. 